\title{
Validation of northern latitude Tropospheric Emission Spectrometer stare ozone profiles with ARC-IONS sondes during ARCTAS: sensitivity, bias and error analysis
}

\author{
C. S. Boxe ${ }^{1}$, J. R. Worden ${ }^{1}$, K. W. Bowman ${ }^{1}$, S. S. Kulawik ${ }^{1}$, J. L. Neu ${ }^{1}$, W. C. Ford ${ }^{2}$, G. B. Osterman ${ }^{1}$, R. L. Herman ${ }^{1}$, \\ A. Eldering ${ }^{1}$, D. W. Tarasick ${ }^{3}$, A. M. Thompson ${ }^{4}$, D. C. Doughty ${ }^{4}$, M. R. Hoffmann ${ }^{5}$, and S. J. Oltmans ${ }^{6}$ \\ ${ }^{1}$ Earth and Space Science Division, Jet Propulsion Laboratory, California Institute of Technology, Pasadena, California, USA \\ ${ }^{2}$ Computation and Neural Systems, California Institute of Technology, 1200 East California Boulevard, Pasadena, \\ CA 91125, USA \\ ${ }^{3}$ Experimental Studies, Air Quality Research Division, Environment Canada, Downsview, Ontario, CA \\ ${ }^{4}$ Department of Meteorology, Pennsylvania State University, University Park, Pennsylvania, USA \\ ${ }^{5}$ Environmental Science and Engineering, California Institute of Technology, 1200 East California Boulevard, Pasadena, \\ CA 91125, USA \\ ${ }^{6}$ NOAA Earth System Research Laboratory, Boulder, Colorado, USA
}

Received: 28 October 2009 - Published in Atmos. Chem. Phys. Discuss.: 17 December 2009

Revised: 29 March 2010 - Accepted: 17 September 2010 - Published: 20 October 2010

\begin{abstract}
We compare Tropospheric Emission Spectrometer (TES) versions 3 and 4, V003 and V004, respectively, nadirstare ozone profiles with ozonesonde profiles from the Arctic Intensive Ozonesonde Network Study (ARCIONS, http: //croc.gsfc.nasa.gov/arcions/) during the Arctic Research on the Composition of the Troposphere from Aircraft and Satellites (ARCTAS) field mission. The ozonesonde data are from launches timed to match Aura's overpass, where 11 coincidences spanned $44^{\circ} \mathrm{N}$ to $71^{\circ} \mathrm{N}$ from April to July 2008. Using the TES "stare" observation mode, 32 observations are taken over each coincidental ozonesonde launch. By effectively sampling the same air mass 32 times, comparisons are made between the empirically-calculated random errors to the expected random errors from measurement noise, temperature and interfering species, such as water. This study represents the first validation of high latitude $\left(>70^{\circ}\right)$ TES ozone. We find that the calculated errors are consistent with the actual errors with a similar vertical distribution that varies between 5\% and 20\% for V003 and V004 TES data. In general, TES ozone profiles are positively biased (by less than $15 \%)$ from the surface to the upper-troposphere $(\sim 1000$ to $100 \mathrm{hPa}$ ) and negatively biased (by less than $20 \%$ ) from the
\end{abstract}

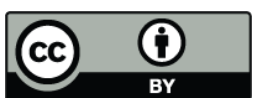

Correspondence to: C. S. Boxe (christopher.boxe@jpl.nasa.gov) upper-troposphere to the lower-stratosphere (100 to $30 \mathrm{hPa}$ ) when compared to the ozonesonde data. Lastly, for V003 and V004 TES data between $44^{\circ} \mathrm{N}$ and $71^{\circ} \mathrm{N}$ there is variability in the mean biases (from -14 to $+15 \%$ ), mean theoretical errors (from 6 to 13\%), and mean random errors (from 9 to $19 \%)$.

\section{Introduction}

The troposphere contains $\sim 10 \%$ of the total ozone in the atmosphere, while the bulk is in the stratosphere. Tropospheric ozone has increased as a consequence of human activities, especially from photochemical processing of combustion products. The environmental impact of this increase depends on the vertical distribution as tropospheric ozone may serve as an air pollutant (lower troposphere), an oxidizing agent (lower-to-middle troposphere) and a greenhouse gas (middle-to-upper troposphere). Therefore, it is essential to map the global three-dimensional distribution of tropospheric ozone and its precursors in order to elucidate factors governing ozone abundances in various regions of the troposphere.

The first large-scale distributions of the tropospheric ozone column as viewed from space were derived from Total Ozone Measurement Spectrometer (TOMS) data (Fishman

Published by Copernicus Publications on behalf of the European Geosciences Union. 
and Larsen, 1987; Fishman et al., 1990). Several residual methods, where the column of stratospheric ozone is subtracted from the total ozone column, have been used to estimate the tropospheric ozone column from TOMS observations (Hudson and Thompson, 1998; Ziemke et al., 1998; Fishman and Balok, 1999; Ziemke et al., 2001, 2003; Newchurch et al., 2003; Schoeberl et al., 2007). Global distributions of tropospheric ozone have also been retrieved from space directly from the Global Ozone and Monitoring Experiment (GOME) (Liu et al., 2005, 2006) and the Ozone Monitoring Instrument (OMI) (Liu et al., 2009). The Interferometric Monitor of Greenhouse Gases (IMG) instrument on the Advanced Earth Observing Satellite (ADEOS) satellite retrieved a limited dataset of nadir profiles of tropospheric ozone, which spanned a brief period from August 1996 to June 1997 (Boynard et al., 2009; Coheur et al., 2005; Turquety et al., 2002). Several limb-viewing satellite instruments, such as the High Resolution Dynamics Limb Sounder (HIRDLS) and Microwave Limb Sounder (MLS), are capable of providing valuable information on upper tropospheric and lower stratospheric ozone, but do not observe the lower troposphere. Furthermore, their vertical information in the upper troposphere-lower stratosphere (UTLS) is inadequate for critical investigations of mechanisms that control the tropospheric ozone distribution.

The Tropospheric Emission Spectrometer (TES), launched on July 2004 on the Earth Observing System Aura (EOSAura) platform, provides a global view of tropospheric ozone, as well as temperature and other tropospheric species, including carbon monoxide, methane, water vapour and its isotopes (e.g., Worden et al., 2007a), and the most recent data product, $\mathrm{NH}_{3}$ (Beer et al., 2001, 2006, 2008). Initially, to document the accuracy of the first release of TES data (V001), TES ozone was validated by comparing about 55 observations from $14^{\circ} \mathrm{S}$ to $59^{\circ} \mathrm{N}$ between September and November, 2004 (Worden et al., 2007b). Thereafter, approximately 1600 TES and ozonesonde coincidences from October 2004 to October $2006\left(73^{\circ} \mathrm{S}\right.$ to $\left.80^{\circ} \mathrm{N}\right)$ were examined to validate TES data version 2 (V002) (Nassar et al., 2008). In the present study, TES data versions 3 and 4, V003 and V004, respectively, are evaluated from April to July, 2008 $\left(44^{\circ} \mathrm{N}\right.$ to $\left.71^{\circ} \mathrm{N}\right)$ using approximately 10 ozonesonde profiles from the Arctic Intensive Ozonesonde Network Study (ARCIONS, http://croc.gsfc.nasa.gov/arcions/), part of the International Polar Year project Arctic Research on the Composition of the Troposphere from Aircraft and Satellites (ARCTAS).

In the Worden et al. (2007b) and Nassar et al. (2008) studies, almost all of the sonde/TES ozone profile comparisons showed significant discrepancies because most of the sonde launches were 50 to $600 \mathrm{~km}$ away from the locations observed by the TES instrument. Despite this additional variability in the comparison due to significant temporal/spatial mismatches between the sonde launches and the TES overpasses, these studies did find that the TES ozone profiles were likely biased high by about $10-15 \%$ in the middle and lower troposphere. A subsequent study by Richards et al. (2008) showed comparisons between TES observations and the differential absorption lidar (DIAL) instrument during the Intercontinental Chemical Transport Experiment - B (INTEX)-B aircraft campaign, with 225 nearcoincident ozone profile measurements. These comparisons also showed a positive bias in the TES tropospheric ozone measurements of between 5-15\% between 20 to $60^{\circ} \mathrm{N}$.

The present analysis differs from these prior validation studies in that the sonde launches were timed to the TES orbit overpasses, and the TES instrument pointed to the location of each sonde launch, thus, greatly reducing the temporal/spatial mismatch of the prior validation measurements. In addition, the TES instrument made thirty-two observations (using the "Stare" observation model) of the air parcel sampled by the sonde within a period of a couple of minutes. Consequently, the observed variability can be attributed almost entirely to the random errors of the TES retrievals, thus, allowing for the first time a comparison between the calculated random errors and the actual random errors. Furthermore, the bias between the TES ozone profiles should be better characterised, because the standard error of the mean between the ensemble of TES ozone profiles from each "stare" as compared to the ozonesonde profile will be much smaller than in the previous studies.

As in the previous studies, the TES averaging kernel and a priori constraint are applied to the sonde data to account for the vertical resolution and measurement sensitivity of TES, which allows for the quantification of both the bias and variability of the TES data versions 3 and 4 nadir-stare ozone dataset.

\section{TES measurements and retrievals}

\subsection{The TES instrument}

TES is an infrared Fourier transform spectrometer with a spectral range from 650 to $3250 \mathrm{~cm}^{-1}$ and a $0.10 \mathrm{~cm}^{-1}$ (apodized) resolution (Beer et al., 2001). In cloud-free conditions, the nadir ozone profiles have approximately four degrees of freedom for signal, approximately two of which are in the troposphere, giving an estimated vertical resolution of about $6 \mathrm{~km}$ (Bowman et al., 2002, 2006; Worden et al., 2004). The footprint is imaged onto an array of 16 detectors with geometric dimensions of approximately 5 by $0.5 \mathrm{~km}$. Under normal operations, however, the spectra from these detectors are averaged, resulting in a horizontal resolution of $5 \times$ $8.5 \mathrm{~km}$. TES, contained on the EOS-Aura platform, is in a near-polar, sun-synchronous, $\sim 705 \mathrm{~km}$ altitude orbit with an equator crossing time of $\sim 13: 45$ local solar time, a 16 day repeat cycle, and a coverage of 16 orbits within $\sim 26 \mathrm{~h}$ via the Global Survey (GS) measurement mode (Schoeberl et al., 2006). 
Table 1. Time overlap between ozonesonde launches and TES overpasses for the 11 TES Coincidences used for V003 and V004 TES data comparisons (http://croc.gsfc.nasa.gov/arcions).

\begin{tabular}{lll}
\hline Ozonesonde Station & Ozonesonde Launch Time (UTC) & TES Overpass (UTC) \\
\hline Bratt's Lake (1) & 2 April, 2008, 20:01 & 2 April, 2008, 20:04 \\
Barrow (2) & 10 April, 2008, 21:58 & 10 April, 2008, 22:35 \\
Barrow (3) & 10 April, 2008, 22:55 & 10 April, 2008, 22:35 \\
Barrow (4) & 12 April, 2008, 20:35 & 12 April, 2008, 22:26 \\
Barrow (5) & 14 April, 2008, 21:45 & 14 April, 2008, 22:13 \\
Bratt's Lake (6) & 18 April, 2008, 19:52 & 18 April, 2008, 20:04 \\
Egbert (7) & 5 July, 2008, 18:36 & 5 July, 2008, 18:35 \\
Egbert (8) & 5 July, 2008, 21:52 & 5 July, 2008, 18:35 \\
Yellowknife (9) & 5 July, 2008, 20:07 & 5 July, 2008, 20:19 \\
Egbert (10) & 7 July, 2008, 17:58 & 7 July, 2008, 18:25 \\
Yellowknife (11) & 7 July, 2008, 17:50 & 7 July, 2008, 20:06 \\
\hline
\end{tabular}

\subsection{TES observation modes}

There are four observation modes used with the TES instrument. The "Global Survey" mode runs every other day and takes one down-looking (nadir) observation approximately every $180 \mathrm{~km}$. TES global survey observations were primarily used in the Worden et al. (2007b) and Nassar et al. (2008) ozone validation studies. Another observation mode used for tropospheric composition or validation campaigns (e.g., INTEX-B or ARCTAS) is the "step-and-stare" mode. In this mode the TES instrument takes one nadir observation approximately every $35 \mathrm{~km}$ over a latitude range of about 60 degrees (or about $\sim 160$ observations total). The ozone comparisons in the Richards et al. (2008) paper used observations from both the global-survey and step-and-stare modes. Two other modes that point the instrument at a specific location instead of looking straight down; these are the "transect" and "stare" modes. The transect mode takes about 30 observations over a distance of approximately $150 \mathrm{~km}$; each observation consists of three measurements (thus, increasing the signal-to-noise by a factor of three); this mode has been used to examine urban locations, for example, Beijing during the time period of the Olympics. The other pointing mode is the stare mode in which TES is pointed at a specified location and takes thirty-two observations; this is the mode used for the comparisons discussed in this paper.

\subsection{Overview of ozone profile retrieval approach}

Atmospheric ozone concentrations are estimated from radiances measured at the $9.6 \mu \mathrm{m}$ ozone band. The algorithms and spectral windows used for TES retrievals of atmospheric state with corresponding error estimation are based on the optimal estimation approach (Rodgers, 2000). Bowman et al. (2002, 2006) describe the TES retrievals methodology, while Worden et al. (2004) and Kulawik et al. (2006a) give a detailed description of the error characterisation. In V003 water vapour, temperature and ozone are retrieved simultaneously in the first step of the retrieval process. In V004 temperature is retrieved by itself in the first step, and then water vapour and ozone are retrieved simultaneously in the second step of the retrieval process. Other species are retrieved in steps, thereafter. Shephard et al. (2008) describes the validation of TES water vapour, and Herman et al. (2010) describes the validation of TES temperature retrievals. The Model of Ozone and Related Tracers (MOZART) (Brasseur et al., 1998; Park et al., 2004) is used to derive the ozone a priori profile (also used as the initial guess), and the covariance matrix is averaged in $10^{\circ}$ latitude $\times 60^{\circ}$ longitude grid boxes. The averaging kernel matrix and a priori constraint matrix are obtained from the Langley Atmospheric Sciences Data Center.

\section{Ozonesonde data}

Ozone and temperature reference data are taken from ozonesonde-radiosonde packages that were launched within the ARCIONS protocol (Arctic Intensive Ozonesonde Network Study; http://croc.gsfc.nasa.gov/arcions; Thompson et al., 2008a, b) during the Arctic Research on the Composition of the Troposphere from Aircraft and Satellites (ARCTAS) experiment in April, late June and early July 2008 (http: //www.espo.nasa.gov/arctas/; Jacob et al., 2010). For the pre-planned TES stare manoeuvres described here, launches were matched as closely as conditions allowed (see Table 1). Table 2 lists the sonde sites and launch dates for the data used in these comparisons, and Table 1 shows the time overlap between ozonesonde launches and TES overpasses.

Electrochemical cell (ECC) ozonesondes were used (Komhyr et al., 1995) with Vaisala RS-80 or RS-92 (in Canada) radiosondes. ECC ozonesondes have a precision of $3-5 \%$ and an absolute accuracy of about $\pm(5-10) \%$ up to $30-\mathrm{km}$ altitude, since differences in sonde manufacture 
Table 2. Ozonesonde Station Locations and Data Providers for the 11 TES Coincidences used for V003 and V004 TES data comparisons (http://croc.gsfc.nasa.gov/arcions).

\begin{tabular}{lllll}
\hline Ozonesonde Station & Latitude & Longitude & Data Source & Date \\
\hline Bratt's Lake & $50^{\circ} \mathrm{N}$ & $105^{\circ} \mathrm{W}$ & ARCIONS & 2 April, 2008 \\
Barrow & $71^{\circ} \mathrm{N}$ & $157^{\circ} \mathrm{W}$ & ARCIONS & 10 April, 2008 \\
Barrow & $71^{\circ} \mathrm{N}$ & $157^{\circ} \mathrm{W}$ & ARCIONS & 12 April, 2008 \\
Barrow & $71^{\circ} \mathrm{N}$ & $157^{\circ} \mathrm{W}$ & ARCIONS & 14 April, 2008 \\
Bratt's Lake & $50^{\circ} \mathrm{N}$ & $105^{\circ} \mathrm{W}$ & ARCIONS & 18 April, 2008 \\
Egbert & $44^{\circ} \mathrm{N}$ & $80^{\circ} \mathrm{W}$ & ARCIONS & 5 July, 2008 \\
Yellowknife & $62^{\circ} \mathrm{N}$ & $114^{\circ} \mathrm{W}$ & ARCIONS & 5 July, 2008 \\
Egbert & $44^{\circ} \mathrm{N}$ & $80^{\circ} \mathrm{W}$ & ARCIONS & 7 July, 2008 \\
Yellowknife & $62^{\circ} \mathrm{N}$ & $114^{\circ} \mathrm{W}$ & ARCIONS & 7 July, 2008 \\
\hline
\end{tabular}

and preparation introduce tropospheric biases of up to $\pm 5 \%$ (Smit et al., 2007; Deshler et al., 2008). The effective vertical resolution of the ozonesondes is about $125 \mathrm{~m}$, due to the balloon ascent rate $(5 \mathrm{~m} / \mathrm{s})$ and response time of $(\sim 25 \mathrm{~s})$ of the ozone-sensing potassium iodide solution. In this study, all ozonesondes reached $30 \mathrm{hPa}$ before burst. Data are provided in ozone mixing ratio on a scale of atmospheric pressure.

\section{Previous validation of TES ozone profiles}

Worden et al. (2007b) provided the first validation of TES ozone version 1 data (V001) with about 55 TES-sonde coincidences, where a time separation of $\pm 48 \mathrm{~h}$ and a $600 \mathrm{~km}$ radius from the sonde station were used as the coincidence criteria. Nassar et al. (2008) provided the second validation of TES ozone version 2 data (V002) with approximately 1600 TES-sonde coincidences and a time separation of $\pm 9 \mathrm{~h}$ and a $300 \mathrm{~km}$ radius from the sonde station as the coincidence criteria. The coincidence criteria of both investigations were chosen to provide TES-sonde measurement pairs that gave a sufficient number of matches for reasonable statistics during Global Surveys, but they should be considered carefully with respect to expected scale dependencies for atmospheric variability. In the Worden et al. (2007b) study, a more ideal $100 \mathrm{~km}$ distance criterion (Sparling and Bacmeister, 2001) would have only yielded three sonde-TES matches. However, the $600 \mathrm{~km}$ criterion that was used to obtain a statistically significant number of TES-sonde matches might be more appropriate for stratospheric variability than for the troposphere (Worden et al., 2007b).

In this work, we exploit the TES stare mode by applying a more stringent criterion of $\pm 3 \mathrm{~h}$ and a direct overpass of sonde. This produced 10 TES-stare and ozonesonde coincidences from April 2008 to July 2008, where each TES-stare mode represented 32 TES observations. The exact separation between the sonde and TES measurements may differ from the stated distances, which are based on the position of the sonde station, due to the horizontal drift of the ozonesonde.
Such horizontal drifts are in general less than $10 \mathrm{~km}$ at the tropopause.

TES data were screened using the "TES ozone data quality flag" (Osterman et al., 2006), the "emission layer flag" (Nassar et al., 2008), and cloud top pressures and cloud effective optical depth (Kulawik et al., 2006b; Eldering et al., 2008). Profiles with thick clouds in the field-of-view were removed because these obscured the infrared emission from the lower troposphere, significantly reducing TES sensitivity. The averaging kernels were used to inspect the optical depth threshold. It permits some cloudiness and, therefore, some reduction in the averaging kernel, but it is a slightly stricter cloud criterion than the effective optical depth $>3.0$ used by Worden et al. (2007b).

\section{Characterisation of TES random and bias errors}

The full characterisation of atmospheric profiles derived from TES radiances has been described previously in Bowman et al. (2002, 2006), Worden et al. (2004) and Kulawik et al. (2006a). We describe this error characterisation as a starting point for deriving the expected versus actual errors from observing the same air mass multiple times.

For any single profile the estimate, $\hat{\boldsymbol{x}}$, can be related to the true state, measurement error, vertical resolution and errors from interfering species:

$\hat{\boldsymbol{x}}=\boldsymbol{x}_{\mathrm{a}}+\mathbf{A}_{\mathrm{xx}}\left(\boldsymbol{x}-\boldsymbol{x}_{\mathrm{a}}\right)+\mathbf{M G}_{\mathrm{z}} \boldsymbol{n}+\mathbf{M G}_{\mathrm{z}} \sum_{i} \mathbf{K}_{i}\left(\boldsymbol{b}_{i}-\boldsymbol{b}_{i}^{a}\right)$,

where the true full state vector $\boldsymbol{x}$ is the log of the ozone mixing ratio (in VMR) at the full 67 TES pressure level grid and the retrieval vector is a subset of this full-state vector, $\mathbf{M}$ is the mapping matrix, $\boldsymbol{x}_{\mathrm{a}}=\boldsymbol{M} z_{\mathrm{c}}$ is the a priori state vector $\left(z_{\mathrm{c}}\right.$ is the a prior retrieval vector), and $\boldsymbol{n}$ is the noise vector. The averaging kernel matrix $\mathbf{A}_{\mathrm{xx}}=\frac{\partial \hat{x}}{\partial \boldsymbol{x}}$ describes the sensitivity of the estimate to the true state profile $\boldsymbol{x}$; note that we can refer to $x$ on the full state grid. The last term in Eq. (1) refers to the sum (subscript i) over all parameters (denoted by $\boldsymbol{b}$ ) 
which could contribute uncertainty to the estimate such as un-retrieved geophysical parameters, for example, temperature, water or spectroscopic line strengths. The Jacobian $\mathbf{K}_{\mathrm{b}}$ describes how dependent the forward model radiance $\mathbf{F}$ is on vector $\boldsymbol{b}$. Note that Eq. (1) does not include bias errors from, for example, instrumental or spectroscopic errors. $\mathbf{G}_{\mathrm{Z}}$ is the gain matrix, which is defined by:

$\mathbf{G}_{\mathrm{z}}=\frac{\partial \boldsymbol{z}}{\partial \mathbf{F}}=\left(\mathbf{K}_{\mathrm{z}}^{\mathrm{T}} \mathbf{S}_{\mathrm{n}}^{-1} \mathbf{K}_{\mathrm{z}}+\Lambda_{\mathrm{z}}\right)^{-1} \mathbf{K}_{\mathrm{z}}^{T} \mathbf{S}_{\mathrm{n}}^{-1}$.

Then $\boldsymbol{n}$ is the zero-mean Gaussian noise vector with convariance $S_{\mathrm{n}}$. The retrieval Jacobian, $\mathbf{K}_{\mathrm{z}}$, is defined by

$\mathbf{K}_{\mathrm{z}}=\frac{\partial \mathbf{F}}{\partial \boldsymbol{x}} \frac{\partial \boldsymbol{x}}{\partial \boldsymbol{z}}=\mathbf{K}_{x} \mathbf{M}$.

The $\Lambda_{z}$ matrix is used to regularize the retrieval; for the TES ozone retrievals this constraint matrix is based on a combination of Tikhanov smoothing constraints and climatologies derived from the MOZART model (Kulawik et al., 2006a). The final term, $\mathbf{S}_{\mathrm{n}}^{-1}$, is the inverse of the measurement error matrix; the diagonals of this matrix are composed of the estimated measurement uncertainty for each spectral element.

The mean of $N$ TES observations is simply:

$\hat{\boldsymbol{x}}_{\mathrm{N}}=\frac{1}{N} \sum_{i=1}^{N} \hat{\boldsymbol{x}}_{i}$

Following Eqs. (1) and (4), the estimated bias error when observing the same air mass is:

$$
\begin{aligned}
\tilde{\boldsymbol{x}}_{\mathrm{N}} & =\hat{\boldsymbol{x}}_{\mathrm{N}}-\boldsymbol{x}=\left(\mathbf{I}-\overline{\mathbf{A}}_{\mathrm{N}}\right)\left(\boldsymbol{x}_{\mathrm{a}}-\boldsymbol{x}\right)+\frac{1}{N} \sum_{i} \mathbf{G}_{i} \boldsymbol{n}_{i} \\
& +\frac{1}{N} \sum_{i} \sum_{1} \mathbf{G}_{i} \boldsymbol{K}_{\mathrm{b}}^{i, l}\left(\boldsymbol{b}_{1}^{i}-\boldsymbol{b}_{\mathrm{a}, 1}^{i}\right)
\end{aligned}
$$

where $\boldsymbol{x}_{\mathrm{a}}$ is the same for all observations and $\overline{\mathbf{A}}_{\mathrm{N}}=\frac{1}{N} \sum_{i=1}^{N} \mathbf{A}_{i}$. In order to calculate the second-order statistics of the estimated bias error, we first make the assumption that $\boldsymbol{n}_{i}$ and $\boldsymbol{b}_{1}^{i}$ are independent, identically distributed random variables for all $N$ observations. Furthermore, we assume that $\boldsymbol{n}_{i}$ and $\boldsymbol{b}_{1}^{i}-\boldsymbol{b}_{\mathrm{a}, 1}^{i}$ are zero-mean, which is an approximation used for spatially and temporally-located measurements. The expected mean bias error is:

$$
E\left[\tilde{\boldsymbol{x}}_{\mathrm{N}}\right]=E\left[\hat{\boldsymbol{x}}_{\mathrm{N}}\right]-\boldsymbol{x}=\left(\mathbf{I}-\overline{\mathbf{A}}_{\mathrm{N}}\right)\left(\boldsymbol{x}-\boldsymbol{x}_{\mathrm{a}}\right)
$$

The covariance of the estimated bias error can be estimated as:

$$
\begin{aligned}
\mathbf{S}_{\tilde{x}} & =E\left[\left(\tilde{\boldsymbol{x}}_{\mathrm{N}}-E\left[\tilde{\boldsymbol{x}}_{\mathrm{N}}\right]\right)\left(\tilde{\boldsymbol{x}}_{\mathrm{N}}-E\left[\tilde{\boldsymbol{x}}_{\mathrm{N}}\right]\right)^{T}\right]=\frac{1}{N^{2}} \sum_{i} \mathbf{G}_{i} \mathbf{S}_{\mathrm{n}} \mathbf{G}_{i}^{T} \\
& +\frac{1}{N^{2}} \sum_{i} \sum_{1} \mathbf{K}_{\mathrm{b}}^{i, l} \mathbf{S}_{\mathrm{b}}^{l}\left(\mathbf{K}_{\mathrm{b}}^{i, l}\right)^{T}
\end{aligned}
$$

where $\mathbf{S}_{\mathrm{b}}$ refers to the dependence of the measurement error matrix on vector $\boldsymbol{b}$, and the spectral noise and systematic errors are assumed to be uncorrelated. Under the condition that for all $i, \mathbf{G}_{i}=\mathbf{G}$ and $\mathbf{K}_{\mathrm{b}}^{i, l}=\mathbf{K}_{\mathrm{b}}^{l}$, then covariance of the estimated bias error reduces to

$\mathbf{S}_{\tilde{x}}=\frac{1}{N} \mathbf{G S}_{\mathrm{n}} \mathbf{G}^{T}+\frac{1}{N} \sum_{1} \mathbf{K}_{\mathrm{b}}^{l} \mathbf{S}_{\mathrm{b}}^{l}\left(\mathbf{K}_{\mathrm{b}}^{l}\right)^{T}$

The standard deviation of the estimated bias error reduces as the square root of $N$ as expected.

We can also examine how well the estimated systematic and random covariance matrices represent the actual variability in the TES retrievals. The sample covariance can be calculated from the TES stare mode as:

$\hat{\mathbf{S}}=\frac{1}{N-1}(\hat{\mathbf{X}}-\overline{\hat{\mathbf{X}}})(\hat{\mathbf{X}}-\overline{\hat{\mathbf{X}}})^{T}$

where $\hat{\mathbf{X}}$ is a matrix whose columns are the retrieved TES profiles, $\hat{\boldsymbol{x}}_{i}$ and $\overline{\hat{\mathbf{X}}}$ is a matrix whose columns are the estimated mean value, $\hat{\boldsymbol{x}}_{\mathrm{N}}$. Assuming that the variability of $\mathbf{G}$ and $\mathbf{K}_{\mathrm{b}}$ are small over the TES stare observations, then:

$\hat{\mathbf{S}} \approx \mathbf{G S}_{\mathrm{n}} \mathbf{G}^{T}+\sum_{1} \mathbf{K}_{\mathrm{b}}^{l} \mathbf{S}_{\mathrm{b}}^{l}\left(\mathbf{K}_{\mathrm{b}}^{l}\right)^{T}$

The error covariance described in Eq. (10) is the observation error covariance found in the TES product. The square root of the diagonal of the covariance described in Eq. (10) can be compared to the root-mean-square of the collection of profiles from the stare, relative to the mean, as described by Eq. (9).

To compare TES ozone profiles with in situ ozonesonde measurements, we first have to account for the variable sensitivity inherent to trace gas and temperature profiles obtained by remote sensing. In addition to the sensitivity to the estimated parameters, the relative effect of the retrieval constraint vector, or a priori, varies with pressure. The general procedure for this operation is described in Rodgers and Connor (2003) and specifically for TES profile/sonde comparisons in Worden et al. (2007b). Its theory and application is described thoroughly by Worden et al. (2004) and Worden et al. (2007b). First, the sonde profile is mapped to the pressure grid used in the TES profile retrievals. Then the instrument operator is applied to this re-mapped sonde profile where the instrument operator is the combination of the averaging kernel and a priori constraint from the TES profile retrieval that is compared to the sonde:

$\hat{\boldsymbol{x}}=\boldsymbol{x}_{\mathrm{a}}+\mathbf{A}_{\mathrm{xx}}\left[\boldsymbol{x}_{\text {sonde }}-\boldsymbol{x}_{\mathrm{a}}\right]$,

Equation (11) quantitatively produces a profile that would be retrieved from TES measurements for the same air sampled by the sonde without the presence of other errors. Therefore, the TES a priori does not bias the TES-sonde difference. 

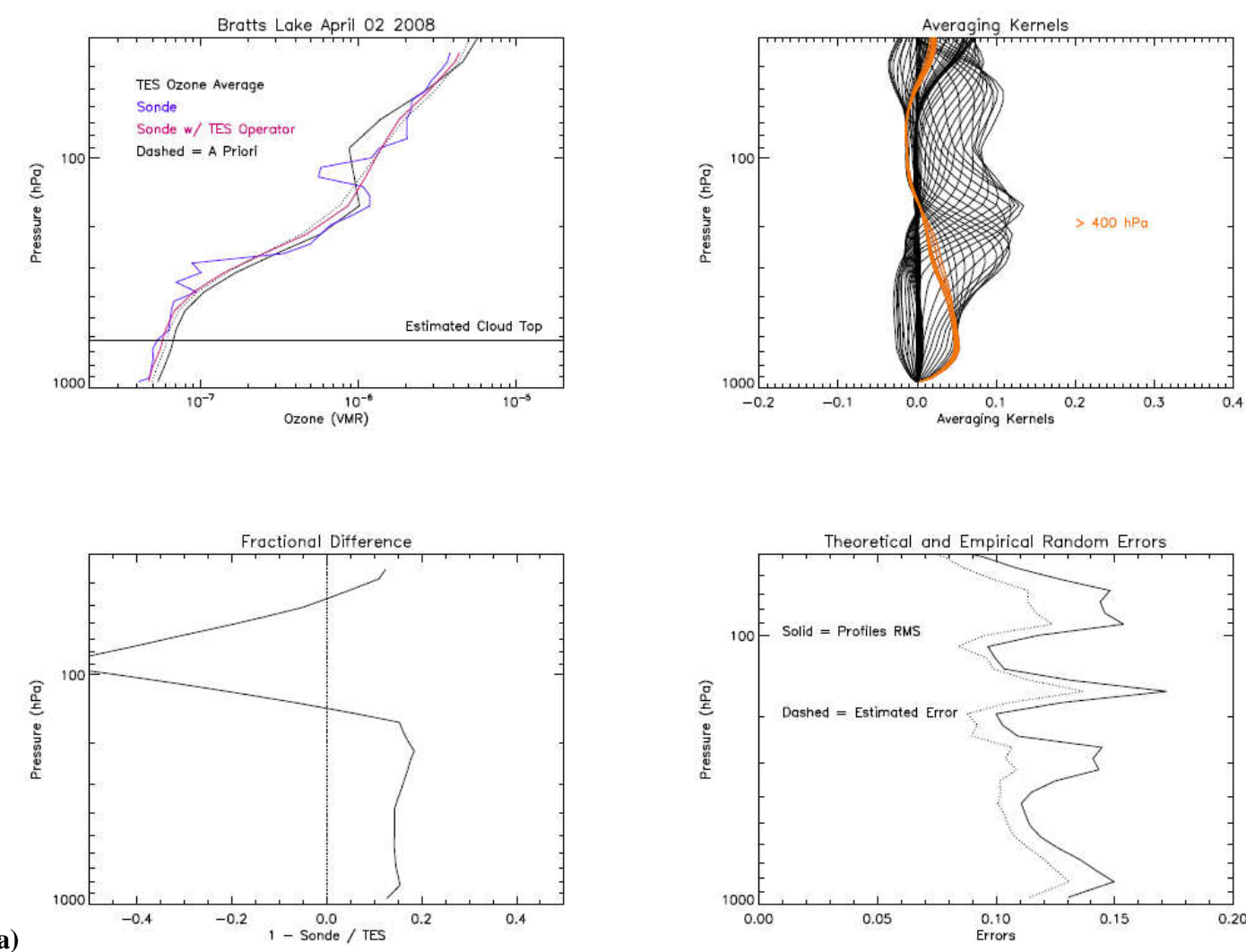

(a)
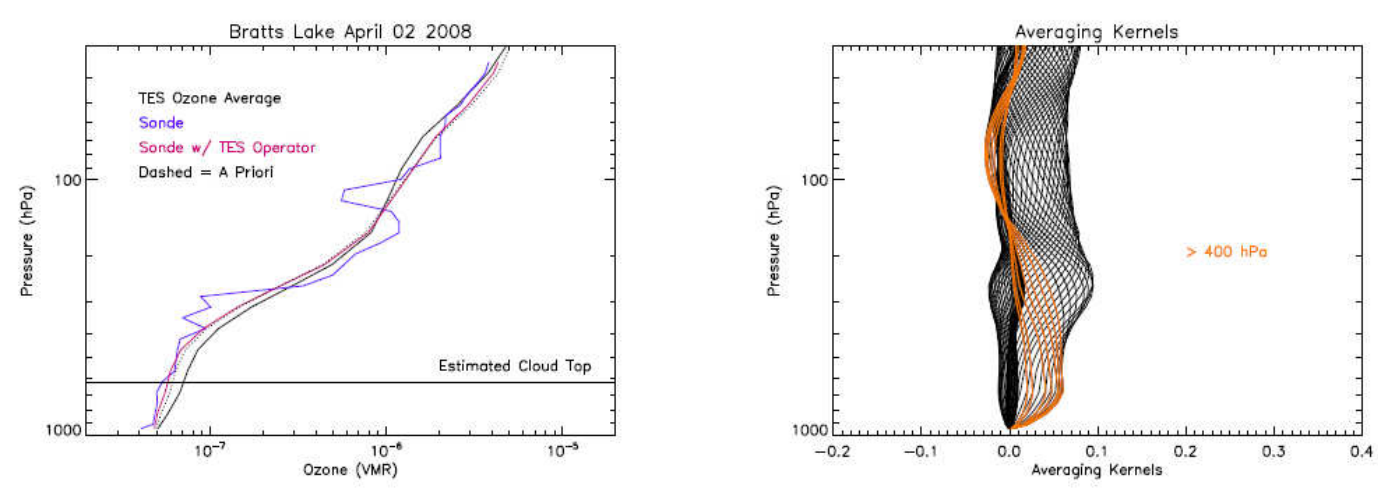

(b)
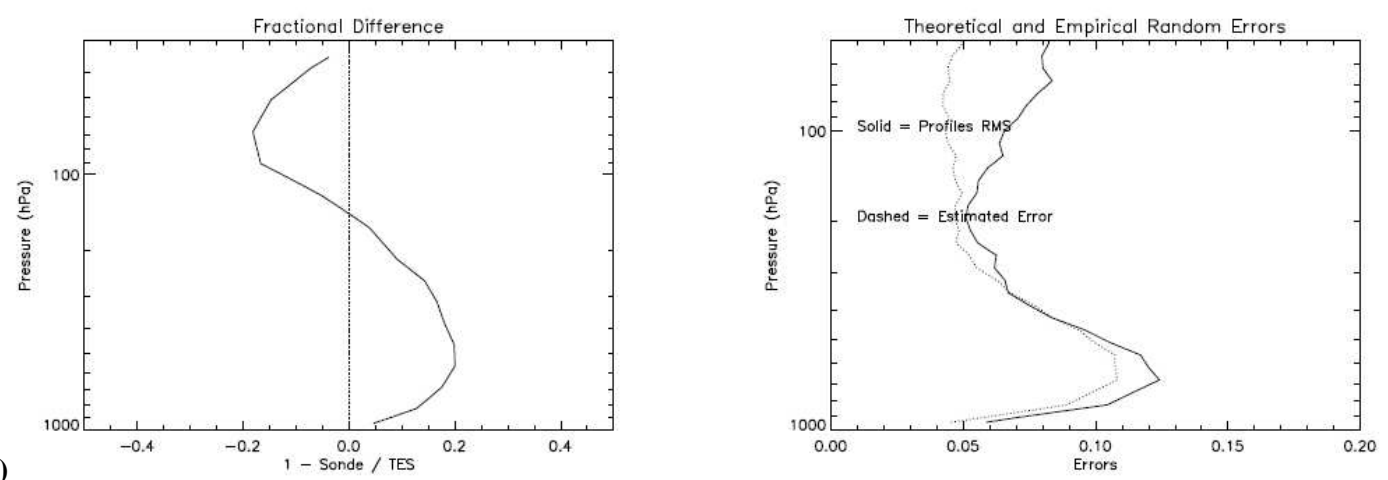

Fig. 1. The TES-stare sequence on 2 April 2008 over Bratt's Lake started at 20:04 (UTC), and the ozonesonde on that day at Bratt's Lake was launched at 20:01 (UTC), using V003 (a) and V004 (b) TES data. 

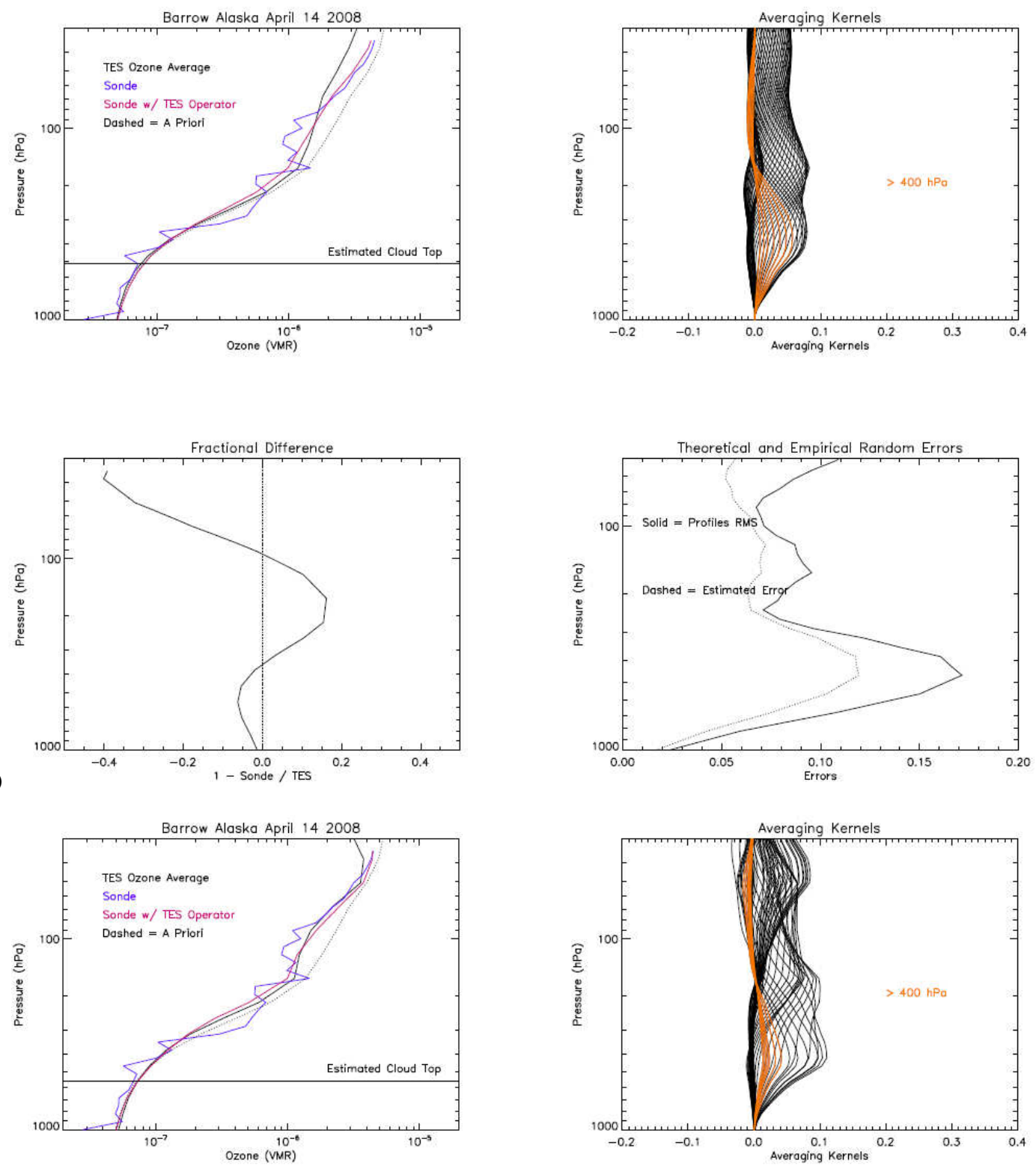

(b)
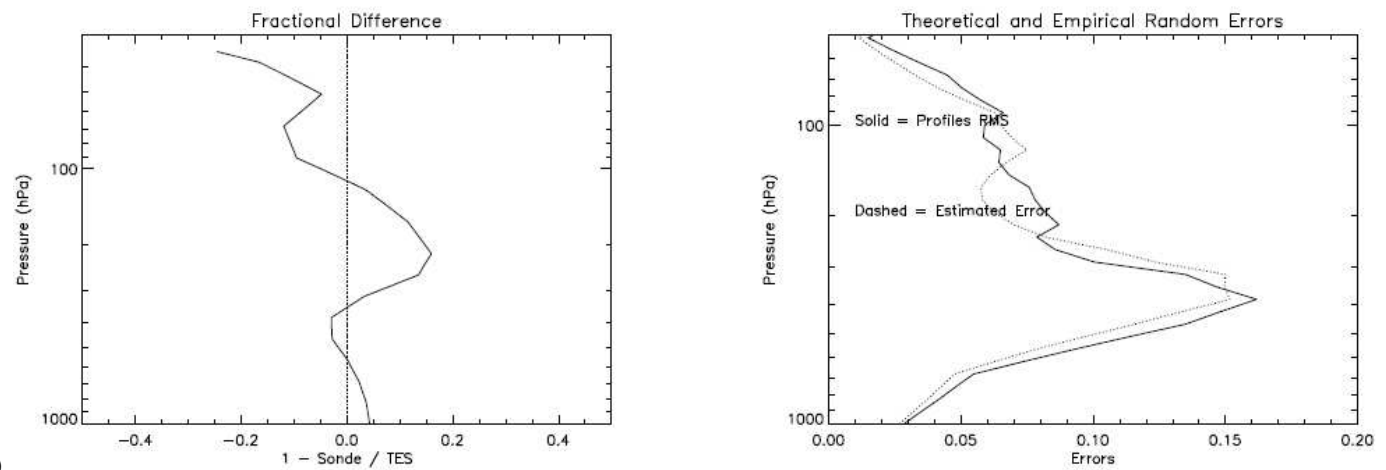

Fig. 2. The TES-stare sequence on 14 April 2008 over Barrow started at 21:45 (UTC), and the ozonesonde on that day at Barrow was launched at 22:13 (UTC), using V003 (a) and V004 (b) TES data. 

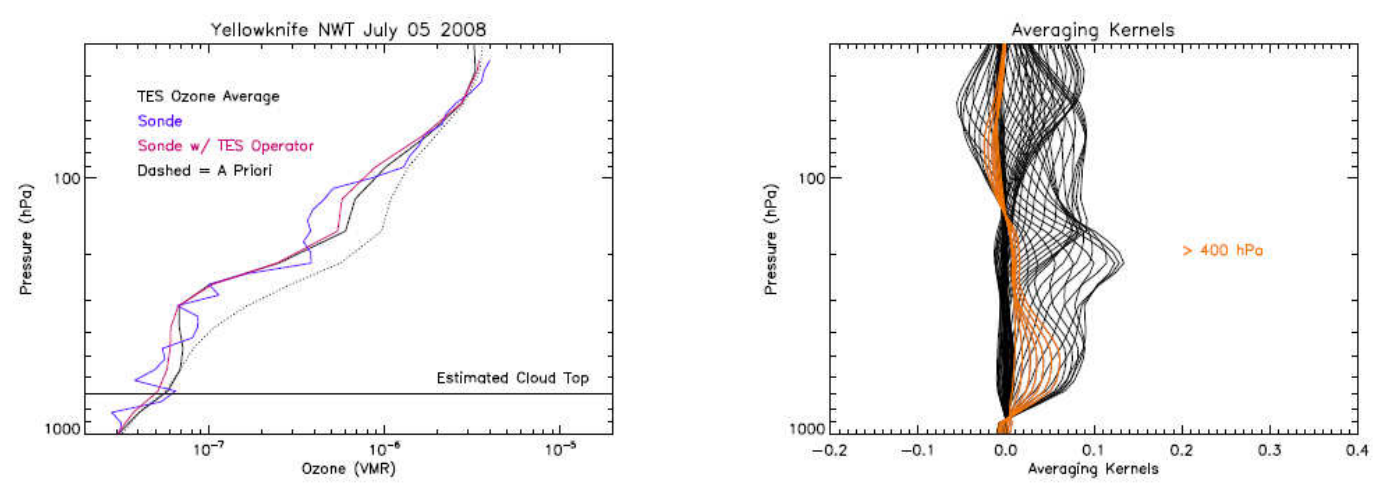

(a)
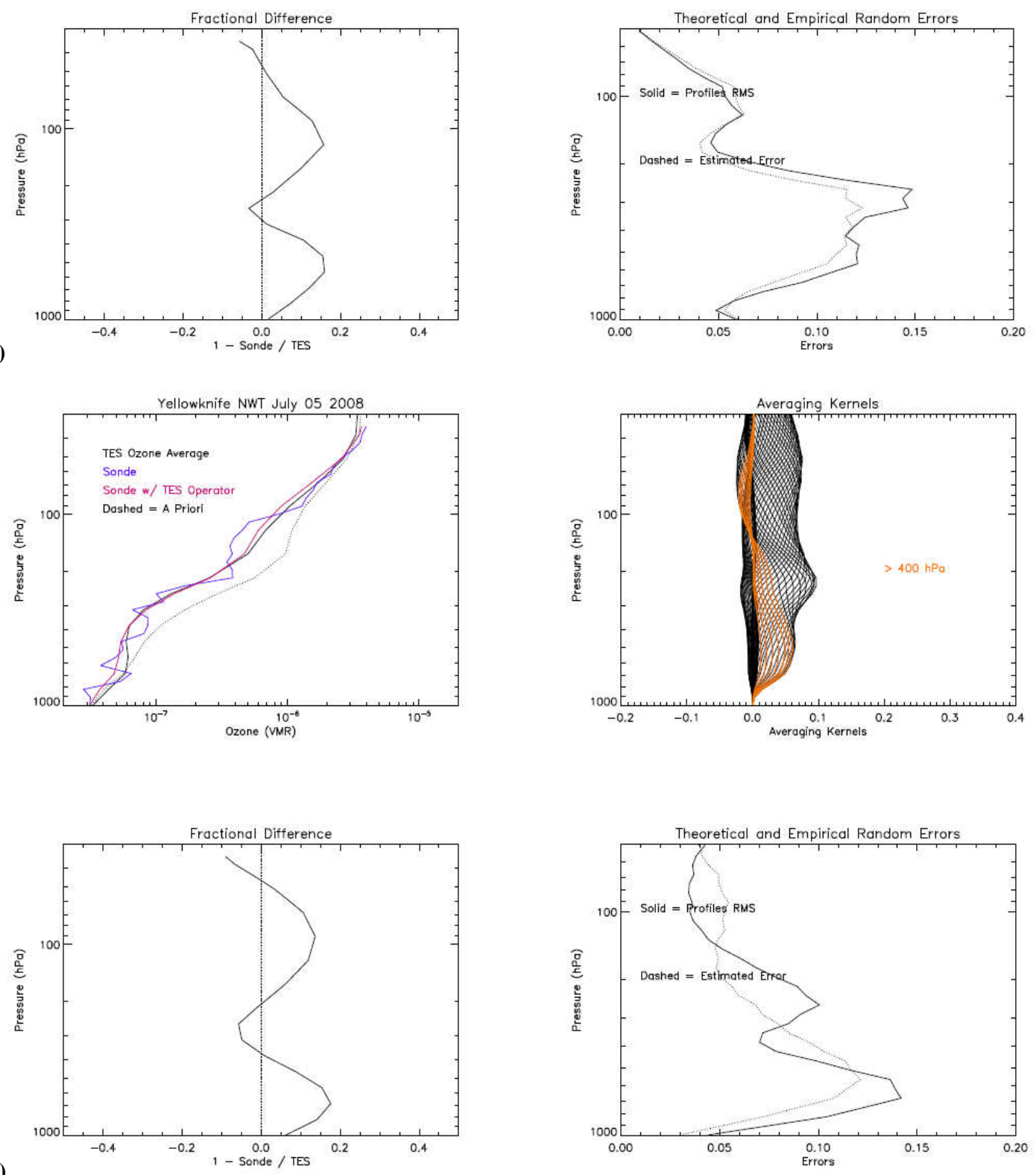

(b)

Fig. 3. The TES-stare sequence on 5 July 2008 over Yellowknife started at 20:19 (UTC), and the ozonesonde on that day at Yellowknife was launched at 20:07 (UTC), using V003 (a) and V004 (b) TES data. 

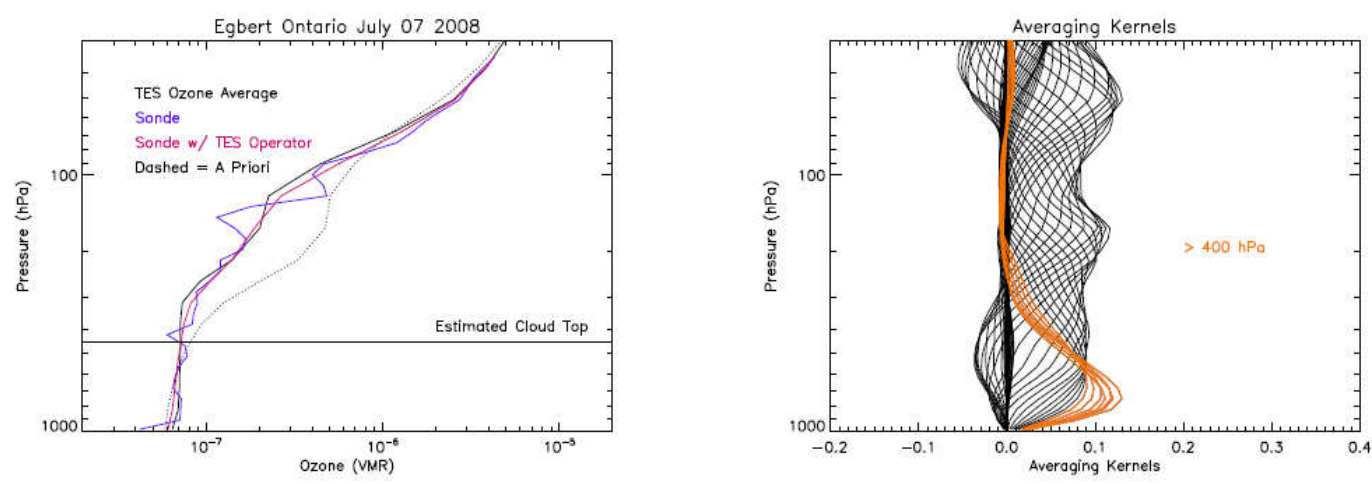

(a)
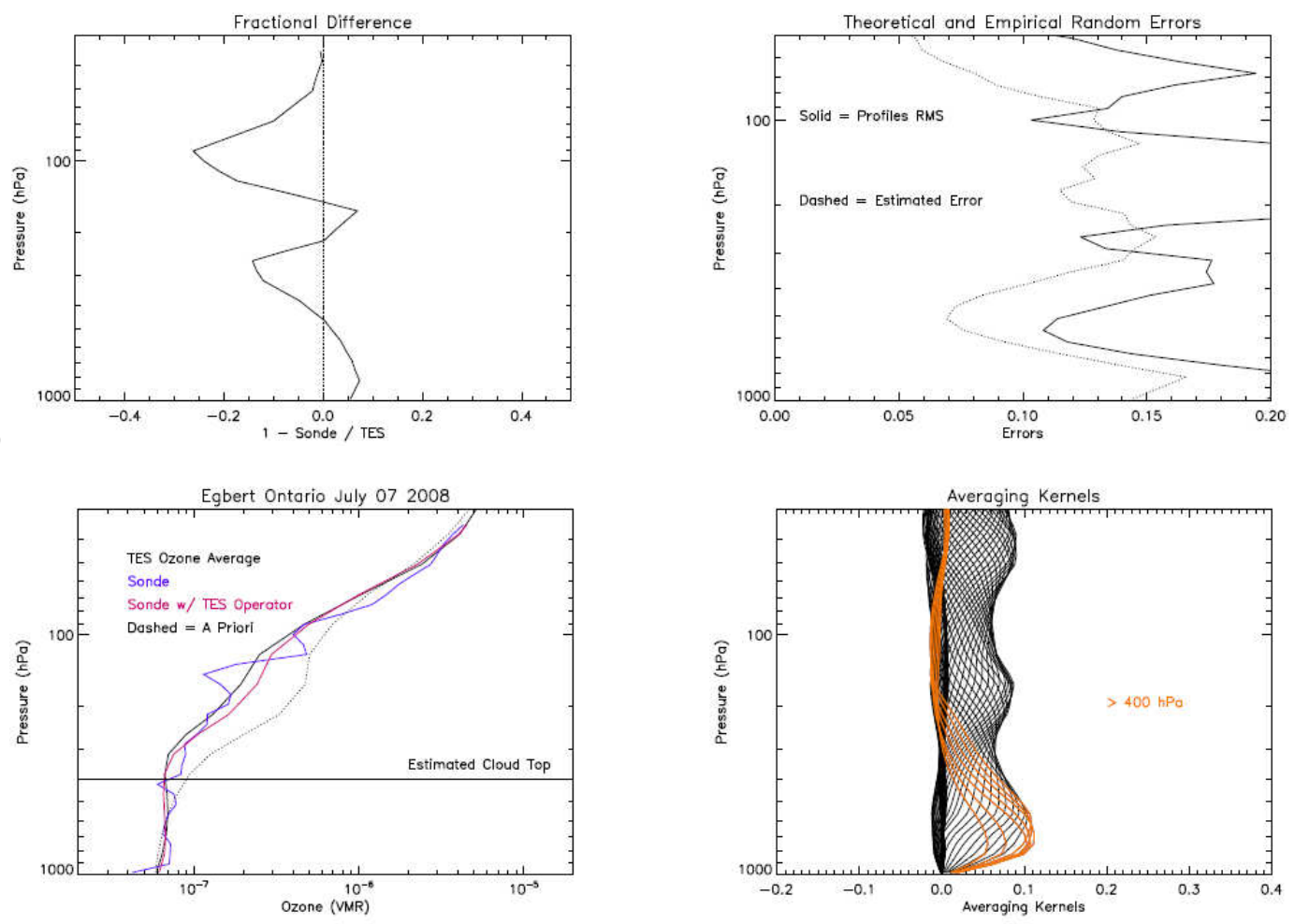

(b)
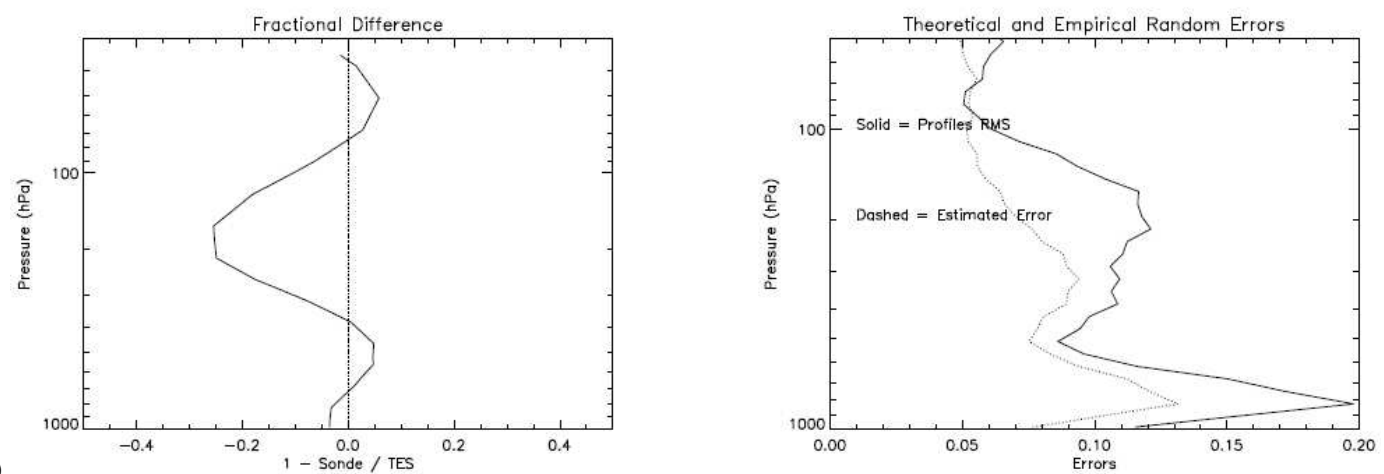

Fig. 4. The TES-stare sequence on 5 July 2008 over Egbert started at 17:58 (UTC), and the ozonesonde on that day at Egbert was launched at 18:25 (UTC), using V003 (a) and V004 (b) TES data. 


\section{Results and discussion}

\subsection{Comparing TES profiles to sondes}

TES-sonde comparisons are summarized in Tables 1 and 2 for Bratt's Lake, Barrow, Yellownife and Egbert. To illustrate the TES-sonde comparison method, we choose TES-ozonesonde coincidence measurements at Bratt's Lake (Fig. 1a and b), Barrow (Fig. 2a and b), Yellowknife (Fig. 3a and b) and Egbert (Fig. 4a and b) on 2 April, 14 April, 5 July and 7 July 2008, respectively. These coincidence measurements are representative of spring and summer during ARCTAS for versions 3 and 4 of the TES $\mathrm{O}_{3}$ data product. The remaining 7 TES-sonde comparisons are included in the supplementary material. The TES-stare sequence on 2 April 2008, over Bratt's Lake started at 20:04 (UTC), and the ozonesonde at Bratt's Lake was launched at 20:01 (UTC) on that day (Fig. 1a and b). The TES-stare sequence on 5 July 2008, over Barrow started at 21:45 (UTC), and the corresponding ozonesonde at Yellowknife was launched at 22:13 (UTC) that day (Fig. 3a and b). The TES-stare sequence on 5 July 2008, over Yellowknife started at 20:19 (UTC), and the corresponding ozonesonde at Yellowknife was launched at 20:07 (UTC) that day (Fig. 3a and b). Lastly, the TES-stare sequence on 5 July 2008, over Egbert started at 18:36 (UTC), and the corresponding ozonesonde at Egbert was launched at 18:35 (UTC) on that day (Fig. 4a and b). All figures juxtapose four profiles: (1) the mean TES profile for 32 scans; (2) the sonde profile; (3) the sonde with the TES operator applied; and (4) the a priori ozone profile. In general, these profiles are similar for both the TES V003 and V004 ozone data product. These plots exemplify how the fine vertical structure of the original sonde data is smoothed by the TES operator via the averaging kernel, $\mathbf{A}_{\mathrm{xx}}$, and the a priori constraint vector, $\boldsymbol{x}_{\mathrm{a}}$. Applying the TES operator produces a profile that represents what TES would measure for the same air sampled by the sonde, in the absence of other errors. Firstly, it can be seen that the sonde variability is within the range of the TES-stare 32 scan for the TES retrievals as shown by Worden et al. (2007b) and Nassar et al. (2008). In general, all the figures display comparable congruence (see supplementary material) for V003 and V004 TES data with the mean TES ozone profile, associated sonde data and associated sonde profiles with the TES operator applied. Simultaneously, for Bratt's Lake and Barrow, Fig. 1a and b and Fig. 2a and b, respectively, TES V004 in comparison to TES V003 clearly reduces the difference between these ozone profiles.

\subsection{TES-nadir-stare ozone-averaging Kernel examples}

TES averaging kernels describe the vertical sensitivity of a retrieval and how the information is smoothed, thereby giving a measure of the vertical resolution. The 11 coincidences show the sensitivity for the TES retrievals to ozone abundances at pressures greater than and less than $400 \mathrm{hPa}$ (ap- proximately the mid-troposphere) in a broad perspective for TES V003 and V004 data under both clear and cloudy conditions. The averaging kernels for TES V003 and V004 retrieval data are given in the upper right panel of each figure. The rows of the averaging kernel matrices are shown which characterise the sensitivity of ozone at any given pressure level to ozone variations at all other pressure levels. For instance, Fig. 4a and b show that for Egbert, Ontario on 7 July 2008 the ozone abundances at pressure levels greater than $300 \mathrm{hPa}$ has an influence on the retrieval of TES V003 and V004 ozone at pressure levels greater than $400 \mathrm{hPa}$; its influence increases with increasing pressure before falling off near the boundary layer. Figure 4 also shows that for this profile, ozone abundances at all altitudes influence TES retrievals at pressure levels less than $400 \mathrm{hPa}$, with more prominent influence at higher altitudes (i.e., at pressures $<300 \mathrm{hPa}$ ). In general, the data show that the influence of the UTLS ozone abundance peaks in the middleto-lower troposphere, while ozone abundance in the stratosphere has the strongest influence on the TES retrieval in the stratosphere, some influence in the upper troposphere, but little influence close to the surface (e.g., Bratt's Lake (2 April 2008, V003 and V004 data, Fig. 1a and b), Bratt's Lake (18 April 2008, V003 and V004 data, see supplementary material), Egbert (5 July 2008, V003 and V004 data, see supplementary material), Egbert (7 July, 2008 V003 and V004, Fig. a and b, and Yellowknife (7 July 2008, V003 data, see supplementary material). However, there are a few cases, such as Barrow (10, 12, and 14 April, Fig. a and b, 2008, V003 and V004 data) and Yellowknife (5 July 2008, V003 and V004 data, Fig. 3a and b), where the TES retrieval of upper-tropospheric-stratospheric ozone (i.e., at pressures below $400 \mathrm{hPa}$ ) has very little influence on lower-tropospheric ozone, especially close to the Earth's surface, which is primarily due to high cloud cover. All figures show averaging kernel examples for TES V003 and V004 retrieval data. They illustrate how the vertical smoothing in TES retrievals combines the information from different pressure levels. For instance, Fig. $4 \mathrm{a}$ and $\mathrm{b}$ show that in general for Egbert, Ontario on 7 July 2008 the ozone abundance at pressures greater than $300 \mathrm{hPa}$ has an increasingly significant influence on the retrieval of TES V003 and V004 ozone at pressures $>400 \mathrm{hPa}$; this figure also shows that ozone abundances at all altitudes influence TES retrievals at pressure levels $<400 \mathrm{hPa}$, where the influence is more prominent at higher pressure levels (i.e., at pressures $<300 \mathrm{hPa}$ ). In general, the averaging kernels are similar for both the TES V003 and V004 ozone data product.

\subsection{Bias between TES retrieval and ozonesonde data}

Worden et al. (2007b) applied the temperature difference criteria and excluded latitudes $>60^{\circ}$, where TES measurements are less reliable because of poor surface characterisation. In order to understand which comparisons are appropriate within the coincidence criteria used in Worden et 
Table 3. Mean bias, theoretical and random errors for V003 TES data comparisons.

\begin{tabular}{lrrr}
\hline $\begin{array}{l}\text { Ozonesonde } \\
\text { Station }\end{array}$ & Bias & $\begin{array}{r}\text { Theoretical } \\
\text { Random Error }\end{array}$ & $\begin{array}{r}\text { Empirical } \\
\text { Random Error }\end{array}$ \\
\hline Bratt's Lake (1) & 0.15 & 0.11 & 0.13 \\
Barrow (2) & 0.002 & 0.07 & 0.09 \\
Barrow (3) & 0.002 & 0.07 & 0.10 \\
Barrow (4) & 0.10 & 0.09 & 0.11 \\
Barrow (5) & 0.02 & 0.07 & 0.07 \\
Bratt's Lake (6) & 0.07 & 0.07 & 0.12 \\
Egbert (7) & 0.11 & 0.11 & 0.19 \\
Egbert (8) & 0.09 & 0.11 & 0.19 \\
Yellowknife (9) & 0.08 & 0.07 & 0.09 \\
Egbert (10) & -0.06 & 0.13 & 0.19 \\
Yellowknife (11) & 0.13 & 0.10 & 0.10 \\
\hline
\end{tabular}

al. (2007b) initial selection of TES measurement with sonde matches, they performed backward trajectories for the locations and times of several TES and sonde measurement pairs. The trajectories were computed with the HYSPLIT transport and dispersion model (Hybrid Single-Particle Lagrangian Integrated Trajectory Model). Worden et al. (2007b) found that there was a distinct relationship between cases with poor temperature comparisons (several pressure levels with $>5 \mathrm{~K}$ differences between TES and sonde in the troposphere) and trajectories that represented different source regions. Worden et al. (2007b), therefore, used sonde-TES temperature differences as an additional filter to select comparison cases for their statistical analysis. This left 43 V001 TES ozone retrieval-ozonesonde coincident pairs for which their respective biases were quantified. The comparison revealed that TES V001 ozone retrievals are biased high compared to sonde measurements in the upper troposphere, with the largest bias around $200 \mathrm{hPa}$. Despite this bias, TES is able to distinguish between high and low ozone abundances in both the lower and upper troposphere and can detect large-scale features in ozone profiles (Worden et al., 2007b). Nassar et al. (2008) also quantified biases for TES V002 retrieved ozone, with a large and wider ranging set of coincident ozonesondes. Considering all latitudes, upper troposphere biases ranged from $2.9 \pm 8.5 \mathrm{ppbv}$ to $10.6 \pm 15.0 \mathrm{ppbv}$. In the lower troposphere, sensitivity of the V002 retrievals in the Arctic was very low so the data was discarded. For the remaining latitude zones, biases ranged from $3.7 \pm 6.9 \mathrm{ppbv}$ to $9.2 \pm 16.3 \mathrm{ppbv}$. These tropospheric biases agree with an evaluation of TES ozone using airborne differential absorption Light Detection and Ranging (LIDAR) (Richards et al., 2008).

Here, we quantify biases for TES V003 and V004 ozone stare retrievals when compared to the coincident ozonesondes from ARCIONS. Although the mean TES profiles are used in quantifying the fractional differences (or biases), the
Table 4. Mean bias, theoretical and random errors for V004 TES data comparisons.

\begin{tabular}{lrrr}
\hline $\begin{array}{l}\text { Ozonesonde } \\
\text { Station }\end{array}$ & Bias & $\begin{array}{r}\text { Theoretical } \\
\text { Random Error }\end{array}$ & $\begin{array}{r}\text { Empirical } \\
\text { Random Error }\end{array}$ \\
\hline Bratt's Lake (1) & 0.11 & 0.07 & 0.10 \\
Barrow (2) & 0.002 & 0.07 & 0.09 \\
Barrow (3) & 0.002 & 0.07 & 0.09 \\
Barrow (4) & 0.01 & 0.06 & 0.09 \\
Barrow (5) & -0.01 & 0.07 & 0.11 \\
Bratt's Lake (6) & 0.06 & 0.07 & 0.12 \\
Egbert (7) & 0.05 & 0.08 & 0.15 \\
Egbert (8) & 0.15 & 0.07 & 0.15 \\
Yellowknife (9) & 0.10 & 0.07 & 0.09 \\
Egbert (10) & -0.14 & 0.08 & 0.11 \\
Yellowknife (11) & 0.12 & 0.09 & 0.13 \\
\hline
\end{tabular}

quantified biases are due to the inherent variability in both the TES ozone retrievals and ozonesonde profiles. For V003 and V004 versions the TES ozone profiles seen here are usually positively biased (by less than 15\%) in the troposphere and lower stratosphere and negatively biased in the middle stratosphere (by less than 20\%) when compared to the ozonesonde data. The first important finding here is that better characterisation of the surface at high latitudes (i.e., $>60^{\circ}$ ) via the retrieval of TES V003 and V004 ozone, allowed for greater sensitivity to ozone and more reliable retrievals; therefore, this validation shows that TES can retrieve robust tropospheric and stratospheric ozone at latitudes greater than $60^{\circ}$, thereby representing the first validation of high latitude ozone. Another important finding is that, despite corresponding variability in TES and sonde measurements, the two measurements yield similar ozone profiles, thereby validating TES within the observed biases. Figures $1 \mathrm{a}$ and $\mathrm{b}$ through Fig. $4 \mathrm{a}$ and $\mathrm{b}$ show profiles of the difference between TES ozone (the mean of the 32 TES scans) and sonde data. Figure 1a and b, describing Bratt's Lake on 2 April 2008, shows a considerable improvement in the TES-sonde ozone bias, throughout the troposphere and stratosphere from V003 to V004; this improvement is more significant in the stratosphere. Figure 2a and b, describing Barrow on 14 April 2008, also shows a considerable improvement in the TES-sonde ozone bias, throughout the troposphere and stratosphere, with the largest improvement in the stratosphere. Figures 3 and $4 \mathrm{a}$ and $\mathrm{b}$ show that, for both V003 and V004 TES ozone data, TES is negatively biased in the stratosphere by no more than $20 \%$ and positively biased in the troposphere by no more than $15 \%$. The mean bias for all V003 and V004 TES data-ozonesonde comparisons are shown in Tables 3 and 4. 


\subsection{Actual random (empirical) versus expected (theoretical) errors}

Multiple sampling of the same air mass, via the TES stareozonesonde coincidence measurements, allows for a comparison between the actual random errors (i.e., the empirical errors), as derived from the root-mean-square of the TES profiles, to the expected errors (i.e., theoretical errors) from measurement noise, temperature and interfering species, such as water. Using Eq. (7), we find that the theoretical errors are generally consistent with the empirical errors, showing analogous vertical distribution to the theoretical errors (see Figs. 1 through 4). Both errors are generally within 5 to $20 \%$ for V003 TES data, while for V004 TES data both errors are generally within 5 to $15 \%$. Overall, as shown in Fig. 1a and b through Fig. 4a and b, V003 and V004 TES data show only a few percent differences between the theoretical and empirical errors. In addition, these figures also show that TES ozone V004 data gives a significant improvement in the theoretical and empirical errors, compared to V003, both in the percent difference between the theoretical and empirical errors and their respective absolute values. For example, TES V004 data for Yellowknife on 5 July 2008 show, overall, an improvement in their empirical and theoretical errors with a significant improvement in the upper troposphere, at approximately $200 \mathrm{hPa}$, from 15 to $10 \%$. In all cases, the actual random errors are larger than the theoretical random errors. This is not surprising as tropospheric ozone profile retrievals are nonlinear because of the influence of stratospheric ozone, as well as other geophysical parameters, such as temperature and water on the estimate. This nonlinearity should impart additional error into the retrieval; we do not calculate this error as it is computationally expensive. The mean theoretical and random errors for all V003 and V004 TES data-ozonesonde comparisons are shown in Tables 3 and 4. Specifically, for V003 and V004 TES data between $44^{\circ} \mathrm{N}$ and $71^{\circ} \mathrm{N}$ there is minor variability in the mean theoretical and mean random errors, ranging from 6 to $+13 \%$ and 9 to $19 \%$, respectively.

\section{Conclusions}

In the present study, TES data versions 3 and 4, V003 and V004, respectively, were validated from April to July 2008 for the middle to high latitudes $\left(44^{\circ} \mathrm{N}\right.$ to $\left.71^{\circ} \mathrm{N}\right)$ by approximately 10 ozonesonde profiles from the Arctic Intensive Ozonesonde Network Study (ARCIONS) component of Arctic Research on the Composition of the Troposphere from Aircraft and Satellites (ARCTAS). This analysis is an update from the validation studies of Worden et al. (2007b) and Nassar et al. (2008) and differs in several ways: (1) this study represents the first validation of high latitude ozone - that is, at latitudes greater than $60^{\circ}$; (2) we use the most current versions of TES data (i.e., versions 3 and 4, V003 and
V004, respectively); (3) we compare for the first time TESstare-sonde coincidence measurements as opposed to TESStep-and-Stare-sonde, TES-Transect-sonde and Global Survey coincidence measurements; (4) the stare mode provides a point (or smaller footprint) assessment of ozone during a specific ozone retrieval sequence; and (5) we characterise actual versus random errors for TES stare profiles. 32 TES observations are taken over the location of the coincident ozonesonde launch, which test whether the predicted errors are consistent with the actual errors. The TES measurement sensitivity and vertical resolution are taken into account by applying the TES-averaging kernel and a priori constraint to the ozonesonde data prior to differencing the profiles. When taking into account the a priori bias and vertical resolution, the predicted errors include noise in the TES radiance measurements and smoothing error, and systematic errors from interfering species, surface emissivity, atmospheric and surface temperature. We find that the calculated observation errors are generally consistent with the empirically derived random errors, both showing analogous vertical distribution. Both error calculations are generally within 5 to $20 \%$ for V003 TES data, while for V004 TES data both error distributions are generally within 5 to $15 \%$. Overall, V003 and V004 TES data show only a few percent differences between the theoretical and empirical errors.

For V003 and V004 versions TES ozone profiles are usually positively biased (less than 15\%) in the troposphere and lower stratosphere and negatively biased in the middle stratosphere (less than 20\%) when compared to ozonesonde data. Lastly, for V003 and V004 TES data between $44^{\circ} \mathrm{N}$ and $71^{\circ} \mathrm{N}$ there is variability in the mean biases (from -14 to $+15 \%$ ), mean theoretical errors (from 6 to $13 \%$ ), and mean random errors (from 9 to 19\%). Our results are consistent with previous analysis and show that the error characterisation of TES profiles is robust given that stratospheric and tropospheric ozone distributions are well captured by the TES data.

\section{Supplementary material related to this article is available online at: http://www.atmos-chem-phys.net/10/9901/2010/ acp-10-9901-2010-supplement.pdf.}

Acknowledgements. The work described here is performed at the Jet Propulsion Laboratory, California Institute of Technology, under contracts with the National Aeronautics and Space Administration.

Edited by: K. Law 


\section{References}

Beer, R., Glavich, T. A., and Ride, D. M.: Tropospheric Emission Spectrometer for the Earth Observing System's Aura Satellite, Appl. Opt., 40, 2356-2367, doi:10.1364/AO.40.002356, 2001.

Beer, R.: TES on the Aura mission: Scientific objectives, measurements, and analysis overview, IEEE T. Geosci. Remote, 44(5), 1102-1105, doi:10.1109/TGRS.2005.863716, 2006.

Beer, R., Shephard, M. W., Kulawik, S. S., et al.: First satellite observations of lower tropospheric ammonia and methanol, Geophys. Res. Lett., 35, L09801, doi:10.1029/2008GL033642, 2008.

Bowman, K., Steck, W. T., Worden, H. M., Worden, J., Clough, S., and Rodgers, C.: Capturing time and vertical variability of tropospheric ozone: A study using TES nadir retrievals, J. Geophys. Res., 107(D23), 4723, doi:10.1029/2002JD002150, 2002.

Bowman K. W., Rodgers, C. D., Kulawik, S. S., et al.: Tropospheric Emission Spectrometer: Retrieval method and error analysis, IEEE T. Geosci. Remote, 44(5), 1297-1307, doi:10.1109/TGRS.2006.871234, 2006

Boynard, A., Clerbaux, C., Coheur, P.-F., Hurtmans, D., Turquety, S., George, M., Hadji-Lazaro, J., Keim, C., and MeyerArnek, J.: Measurements of total and tropospheric ozone from IASI: comparison with correlative satellite, ground-based and ozonesonde observations, Atmos. Chem. Phys., 9, 6255-6271, doi:10.5194/acp-9-6255-2009, 2009.

Brasseur, G. P., Hauglustaine, D. A., Walters, S., Rasch, P. J., Muller, J. F., Granier, C., and Tie, X. X.: MOZART, a global chemical transport model for ozone and related chemical tracers: 1. Model description, J. Geophys. Res., 103, 28265-28289, doi:10.1029/98JD02397, 1998.

Coheur, P.-F., Barnet, B., Turquety, S., Hurmans, D., Hadjii-Lazaro, J., and Clerbaux, C.: Retrieval and characterisation of ozone vertical profiles from a thermal infrared nadir sounder, J. Geophys. Res., 110, D24303, doi:10.1029/2005JD005845, 2005.

Deshler, T., Mercer, J. M., Smit, H. G. J., et al.: Atmospheric comparison of electrochemical cell ozonesondes from different manufacturers, and with different cathode solution strengths: The Balloon Experiment on Standards for Ozonesondes, J. Geophys. Res., 113, D04307, doi:10.1029/2007D008858, 2008.

Eldering, A., Kulawik, S. S., Worden, J. R., Bowman, K. W., and Osterman, G. B.: Implementation of cloud retrievals for Tropospheric Emission Spectrometer atmospheric retrievals: 2. Characterization of cloud top pressures and effective optical depth retrievals, J. Geophys. Res., 113, D16S37, doi:10.1029/2007D008858, 2008.

Fishman, J. and Larsen, J. C.: Distribution of total ozone stratospheric ozone in the tropics: Implications for the distribution of tropospheric ozone, J. Geophys. Res., 92, 6627-6634, 1987.

Fishman, J., Watson, C. E., Larsen, J. C., and Logan, J. A.: The distribution of tropospheric ozone obtained from satellite data, J. Geophys. Res., 95, 3599-3617, 1990.

Fishman, J. and Balok, A.: Calculation of daily tropospheric ozone residuals using TOMS and empirically improved SBUV measurements: Application to an ozone pollution episode over the eastern United States, J. Geophys. Res., 104, 30319-30340, 1999.

Herman, R. L., Fisher, B. M., Shephard, M. W., et al.: : Tropospheric Emission Spectrometer Version 4 Temperature Retrievals Compared with Aircraft and Sondes, in preparation, 2010.

Hudson, R. D. and Thompson, A. M.: Tropical tropospheric ozone from total ozone mapping spectrometer by a modified residual method, J. Geophys. Res., 103(D17), 22129-22146, doi:10.1029/98JD00729, 1998.

Jacob, D. J., Crawford, J. H., Maring, H., Clarke, A. D., Dibb, J. E., Ferrare, R. A., Hostetler, C. A., Russell, P. B., Singh, H. B., Thompson, A. M., Shaw, G. E., McCauley, E., Pederson, J. R., and Fisher, J. A.: The ARCTAS aircraft mission: design and execution, Atmos. Chem. Phys. Discuss., 9, 17073-17123, doi:10.5194/acpd-9-17073-2009, 2009.

Jacob, D. J., Crawford, J. H., Maring, H., Clarke, A. D., Dibb, J. E., Emmons, L. K., Ferrare, R. A., Hostetler, C. A., Russell, P. B., Singh, H. B., Thompson, A. M., Shaw, G. E., McCauley, E., Pederson, J. R., and Fisher, J. A.: The Arctic Research of the Composition of the Troposphere from Aircraft and Satellites (ARCTAS) mission: design, execution, and first results, Atmos. Chem. Phys., 10, 5191-5212, doi:10.5194/acp-10-5191-2010, 2010.

Komhyr, W. D., Barnes, R. A., Brothers, G. B., Lathrop, J. A., and Opperman, D. P.: Electrochemical concentration cell ozonesonde performance evaluation during STOIC 1989, J. Geophys. Res., 100, 9231-9244, doi:10.1029/94JD02175, 1995.

Kulawik, S. S., Worden, H., Osterman, G., et al.: TES atmospheric profile retrieval characterisation: An orbit of simulated observations, IEEE T. Geosci. Remote, 44(5), 1324-1332, doi:10.1109/TGRS.2006.871207, 2006a.

Kulawik, S. S., Worden, J., Eldering, A., et al.: Implementation of cloud retrievals for Tropospheric Emission Spectrometer (TES) atmospheric retrievals: 1 . Description and characterisation of errors on trace gas retrievals, J. Geophys. Res., 111, D24204, doi:10.1029/2005JD006733, 2006b.

Liu, X., Chance, K., Sioris, C. E., Spurr, R. J. D., Kurosu, T. P., Martin, R. V., and Newchurch, M. J.: Ozone profile and tropospheric ozone retrievals from the Global Ozone Monitoring Experiment Algorithm description and validation, J. Geophys. Res., 110, D20307, doi:10.1029/2005JD006240, 2005.

Liu, X., Chance, K., Sioris, C. E., et al.: First directly retrieved global distribution of tropospheric column ozone from GOME: Comparisons to the GEOS-Chem model, J. Geophys. Res., 111, D02308, doi:10.1029/2005JD006564, 2006.

Liu, X., Bhartia, P. K., Chance, K., Spurr, R. J. D., and Kurosu, T. P.: Ozone profile retrievals from the Ozone Monitoring Instrument, Atmos. Chem. Phys. Discuss., 9, 22693-22738, doi:10.5194/acpd-9-22693-2009, 2009.

Nassar, R., Logan, J. A., Worden, H. M., et al.: Validation of Tropospheric Emission Spectrometer (TES) nadir ozone profiles using ozonesonde measurements, J. Geophys. Res., 113, D15S17, doi:10.1029/2007JD008819, 2008.

Newchurch, M. J., Sun, D., Kim, J. H., and Liu, X.: Tropical tropospheric ozone derived using Clear-Cloudy Pairs (CCP) of TOMS measurements, Atmos. Chem. Phys., 3, 683-695, doi:10.5194/acp-3-683-2003, 2003.

Osterman, G., Bowman, K., Eldering, A., et al.: Tropospheric Emission Spectrometer TES L2 Data User's Guide Version 2.00, 1 June 2006, Jet Propul. Lab., Calif. Inst. Of Technol., Pasadena, Calif., 2006.

Park, M., Randel, W. J., Kinnison, D. E., Garcia, R. R., and Choi, W.: Seasonal variations of methane, water vapour, ozone, and nitrogen dioxide near the tropopause: Satellite observations and model simulations, J. Geophys. Res., 109, D03302, doi:10.1029/2003JD003706, 2004. 
Richards, N., Osterman, G. B., Browell, E. V., Hair, J., Avery, A., and Li, Q. B.: Validation of Tropospheric Emission Spectrometer (TES) ozone profiles with aircraft observations during INTEXB, J. Geophys. Res., 113, D16S29, doi:10.1029/2007JD008815, 2008.

Rodgers, C. D.: Inverse Methods for Atmospheric Sounding: Theory and Practice, World Sci., London, 2000.

Rodgers, C. D. and Connor, B. J.: Intercomparison of remote sounding instruments, J. Geophys. Res., 108(D3), 4116, doi:10.1029/2002JD002299, 2003.

Schoeberl, M. R., Douglass, A. R., Hilsenrath, E., et al.: Overview of the EOS Aura Mission, IEEE T. Geosci. Remote, 44(5), 10661074, 2006.

Schoeberl, M. R., Ziemke, J. R., Livesey, N., et al.: A Trajectory Based Estimate of the Tropospheric Column Ozone Column Using the Residual Method, J. Geophys Res., 112, D24S49, doi:10.1029/2007JD008773, 2007.

Shephard, M. W., Herman, R. L., Fisher, B. M., et al.: Comparison of Tropospheric Emission Spectrometer (TES) nadir water vapour retrievals with in situ measurements, J. Geophys. Res., 113, D15824, doi:10.1029/2007JD008822, 2008.

Smit, H. G. J., Straeter, W., Johnson, B. J., et al.: Assessment of the performance of ECC-ozonesondes under quasi-flight conditions in the environmental simulation chamber: Insights from the Julich Ozone Sonde Intercomparison Experiment (JOSIE), J. Geophys. Res., 112, D19306, doi:10.1029/2006JD007308, 2007.

Sparling, L. C. and Bacmeister, J. T.: Bacmeister Scale dependence of tracer microstructure: PDFs, intermittency and the dissipation scale, Geophys. Res. Lett., 28, 2823-2826, 2001.

Thompson, A. M., Yorks, J. E., Miller, S. K., Witte, J. C., Dougherty, K. M., Morris, G. A., Baumgardner, D., Ladino, L., and Rappenglück, B.: Tropospheric ozone sources and wave activity over Mexico City and Houston during MILAGRO/Intercontinental Transport Experiment (INTEX-B) Ozonesonde Network Study, 2006 (IONS-06), Atmos. Chem. Phys., 8, 5113-5125, doi:10.5194/acp-8-5113-2008, 2008a.
Thompson, A. M., Luzik, A. M., Doughty, D. C., et al.: Tropospheric ozone surface depletion (spring) and pollution (summer) in 2008 from the ARCTAS Intensive Ozonesonde Network Study (ARC-IONS) soundings, Eos, Trans. AGU, 89(53), Fall Meeting Supple., Abstract A11A-0097, 2008b.

Turquety, S., Hadji-Lazaro, J., and Clerbaux, C.: First satellite ozone distributions retrieved from nadir high-resolution infrared spectra, Geophys. Res. Lett., 29(24), 2198, doi:10.1029/2002GL016431, 2002.

Worden, H., Kulawik, S. S., Shephard, M. W., et al.: Predicted errors of tropospheric emission spectrometer nadir retrievals from spectral window selection, J. Geophys. Res., 109, D09308, doi:10.1029/2004JD004522, 2004.

Worden, J., Noone, D., Bowman, K., et al.: Importance of rain evaporation and continental convection in the tropical water cycle, 445, 528-532, 2007a.

Worden, H. M., Logan, J. A., Worden, J. R., et al.: Comparisons of Tropospheric Emission Spectrometer (TES) ozone profiles to ozonesondes: Methods and initial results, J.Geophys. Res., 112, D03309, doi:10.1029/2006JD007258, 2007b.

Ziemke, J. R., Chandra, S., and Bhartia, P. K.: Two new methods for deriving tropospheric column ozone from TOMS measurements: Assimilated UARS MLS/HALOE and convective-cloud differential techniques, J. Geophys. Res., 103(D17), 22115-22128, doi:10.1029/98JD01567, 1998.

Ziemke, J. R., Chandra, S., and Bhartia, P. K.: "Cloud slicing": A new technique to derive upper tropospheric ozone from satellite measurements, J. Geophys. Res., 106(D9), 9853-9867, doi:10.1029/2000JD900768, 2001.

Ziemke, J. R., Chandra, S., and Bhartia, P. K.: Upper tropospheric ozone derived from the cloud slicing technique: Implications for large-scale convection, J. Geophys. Res., 108(D13), 4390, doi:10.1029/2002JD002919, 2003. 